\title{
POTENSI RIDESHARING DAN ANTAR JEMPUT PEGAWAI BALAIKOTA SURAKARTA SEBAGAI IMPLEMENTASI GREEN TRANSPORTATION
}

\author{
BR Revandy Baskara Jati1) Dewi Handayani2) Amirotul MHM3) \\ 1) Mahasiswa Fakultas Teknik, Program Studi Teknik Sipil, Universitas Sebelas Maret \\ 2),3) Pengajar Fakultas Tenik, Program Studi Teknik Sipil, Universitas Sebelas Maret \\ Jln Ir. Sutami 36A, Surakarta 57126; Telp. 0271-634524. \\ Email: realinorevandy@gmail.com
}

\begin{abstract}
The city of Surakarta has signed a charter of Green City Commitments on November 7, 2011. But by 2017 the concept of green transportation as part of green city commitment has not been fully implemented, this is seen from the number of private vehicles used for daily needs. Ridesharing and employee shuttle facility is one of alternative solution to support green transportation policy. Therefore, the goal to be achieved in this research is to know the characteristics of private vebicle users in the City Hall parking facilities and get a number of potential employees who are willing to do ridesharing or pickup.

Primary data was obtained by distributing questionnaires to the employees of Surakarta City Hall users of motorcycles and car users in several offices based in the complex of the City Hall of Surakarta. The survey forms are grouped into 2 forms, namely the form 1 contains the respondent characteristic data and the form 2 contains the responses of respondents to ridesharing and shuttle employees. Further data obtained will be analyzed by descriptive analysis method.

Employees who are willing to use ridesharing amounted to $55.32 \%$ for cars and $31.68 \%$ for motorcycles. Thus, there is a potential reduction in the use of car and motor parking facilities in the Surakarta City Hall complex up to 25.53\% for cars and 14.29\% for motorcycles. Employees who are willing to use shuttle facilities amounted to $46.81 \%$ for car users and $39.75 \%$ for motor users. That way there is a potential for the reduction of car use by employees of the City Hall Surakarta maximum of $46.81 \%$ and motorycles amounted to $39.75 \%$.
\end{abstract}

Keywords: green transportation, ridesharing, shuttle bus, staff.

\begin{abstract}
Abstrak
Kota Surakarta telah menandatangani piagam “Komitmen Kota Hijau” pada tanggal 7 November 2011. Namun pada hingga tahun 2017 konsep green transportation sebagai bagian dari Komitmen Kota Hijau belum sepenuhnya dijalankan, dilihat dari masih banyaknya kendaraan pribadi yang digunakan untuk kebutuhan sehari - hari. Ridesharing dan fasilitas antar jemput pegawai merupakan salah satu solusi alternatif pendukung kebijakan green transportation. Oleh karena itu, Tujuan yang ingin dicapai dalam penelitian ini adalah untuk mengetahui karateristik pengguna kendaraan pribadi di fasilitas parkir Balaikota serta mendapatkan besar potensi pegawai yang bersedia melakukan ridesharing atau antar jemput.

Data primer diperoleh dengan menyebarkan kuisioner kepada pegawai Balaikota Surakarta pengguna sepeda motor dan pengguna mobil di beberapa dinas yang berkantor di kompleks Balaikota Surakarta. Formulir survei dikelompokkan menjadi 2 bentuk formulir, yaitu formulir 1 berisi data karakteristik responden dan formulir 2 berisi tanggapan responden terhadap ridesharing dan antar jemput pegawai. Selanjutnya data yang diperoleh akan dianalisa dengan metode analisis deskriptif.

Pegawai yang bersedia menggunakan ridesharing adalah sebesar 55,32\% untuk mobil dan 31,68\% untuk motor. Dengan begitu maka terdapat potensi pengurangan penggunaan fasilitas parkir mobil dan motor di kompleks Balaikota Surakarta maksimal sebesar 25,53\% untuk mobil dan 14,29\% untuk motor. Pegawai yang bersedia menggunakan fasilitas antar jemput sebesar 46,81\% untuk pengguna mobil dan 39,75\% untuk pengguna motor. Dengan begitu terdapat potensi lanjutan berupa pengurangan penggunaan mobil oleh pegawai Balaikota Surakarta maksimal sebesar 46,81\% dan motor sebesar 39,75\%.
\end{abstract}

Kata kunci: antar jemput, green transportation, pegawai, ridesharing.

\section{PENDAHULUAN}

Ridesharing dan antar jemput pegawai cukup banyak diteliti dan dilakukan dengan berbagai metode sesuai hasil yang ingin dicari. Penelitian dengan tujuan mencari besar potensi ridesharing dan antar jemput pegawai pernah dilakukan sebelumnya. Beberapa penelitian yang pernah ada berkaitan dengan ridesharing dan antar jemput dijabarkan pada paragraf selanjutnya.

Penelitian mengenai potensi penerapan fasilitas antar jemput telah dilakukan oleh Rudy Setiawan (2007), penelitian ini dilakuan berdasarkan studi kasus di Universitas Kristen Petra Surabaya. Dalam penelitian ini Setiawan (2007) bertujuan untuk mengetahui seberapa besar dampak penerapan fasilitas antar-jemput bagi mahasiswa untuk mengurangi penggunaan mobil pribadi di Universitas Kristen Petra. Metode analisis yang digunakan adalah statistik deskriptif yang diperoleh melalui penyebaran kuisioner. Hasil yang didapat adalah penerapan antar jemput berpotensi mengurangi penggunaan mobil pribadi oleh mahasiswa sebesar 50,6\%.

Jacobson dan King (2008), telah melakukan penelitian yang berjudul penghematan bahan bakar dan ridesharing di Amerika Serikat yang berorientasi pada motivasi, keterbatasan, dan peluang. Penelitian ini bertujuan untuk mencari 
tahu seberapa besar potensi untuk penghematan bahan bakar yang diakibatkan adanya kebijakan ridesharing. Metode penelitian yang digunakan adalah pemodelan statistik berdasarkan data statistik yang telah tersedia untuk publik. Pada penelitian ini, variabel yang diteliti adalah kecepatan kendaraan, jarak perjalanan, waktu penjemputan saat melakukan carpool, harga bahan bakar kendaraan, dan berat badan penumpang. Hasil dari penelitian ini adalah potensi penghematan yang dapat dilakukan akibat adanya peningkatan penggunaan ridesharing oleh kendaraan non - komersial di Amerika Serikat sangatlah besar, yaitu penambahan satu penumpang pada setiap 100 kendaraan akan mampu menghemat 0,80-0,82 milyar galon bensin setiap tahunnya dan penambahan satu orang penumpang terjadi pada setiap 10 kendaraan maka potensi penghematan yang dapat dilakukan adalah sebesar 7,54-7,74 milyar galon bensin setiap tahunnya.

Sebuah penelitian mengenai efektivitas intervensi berbasis web untuk mendorong carpooling untuk bekerja telah dilakukan oleh Abrahamse dan Keall (2012) di Wellington, New Zealand. Penelitian ini bertujuan untuk menguji efektifitas skema carpool regional, dalam hal ini perubahan pada pemilihan moda dan frekuensi untuk mengemudi sendiri, serta menguji faktor-faktor yang terkait dengan pengendara tunggal. Metode yang dilakukan untuk mengumpulkan data dalam penelitian ini adalah melalui survei online dengan aplikasi Let's Carpool, sedangkan metode yang digunakan untuk menganalisis data adalah dengan hierarchical regression analysis. Variabel yang diteliti dalam penelitian ini adalah preferensi pemilihan moda, frekuensi penggunaan kendaraan pribadi, usia, pendapatan, pekerjaan, frekuensi perjalanan menuju kantor, dan latar belakang mengikuti carpool. Hasil yang didapat dari penelitian ini adalah penggunaan terhadap aplikasi Let's Carpool sukses mendorong orang untuk berpindah ke sistem carpool, dilihat dari peningkatan presentase pengguna carpooling dari 12,4\% menjadi 27,9\%. Hasil lain adalah bahwa kombinasi dari informasi personal mengenai kecocokan carpool dan insentif yang diberikan lewat web mampu mendorong orang untuk mengadopsi kebijakan carpooling.

Penelitian mengenai potensi pengembangan program ridesharing berdasarkan preferensi pekerja telah dilakukan oleh Rachman dan Kusumantoro (2013). Penelitian ini dilakukan di kawasan perumahan kemang pratama kota Bekasi dengan metode deskriptif kuantitatif. Hasil survey data yang telah diperoleh kemudian dianalisis menggunakan metode analisis tabulasi silang dengan menggunakan alat statistik chi-square untuk mengetahui hubungan antar variabel. Tujuan dari penelitian ini adalah untuk mengetahui potensi pengembangan program ridesharing berdasarkan preferensi tempat bekerja. Variabel yang diteliti antara lain yaitu, latar belakang sosial ekonomi, jenis kelamin, jenis pekerjaan, waktu tempuh, jarak jemput, lokasi tujuan, dan tingkat mobilitas pekerjaan. Hasil dari penelitian ini adalah ridesharing yang akan dikembangkan memiliki potensi mereduksi jumlah kendaraan (mobil) yang berlalu-lalang sebanyak 15 mobil atau sebesar 9,61\%.

Oleh karena itu, tujuan yang ingin dicapai dalam penelitian ini adalah untuk mengetahui karateristik pengguna kendaraan pribadi di fasilitas parkir Balaikota serta mendapatkan besar potensi pegawai yang bersedia melakukan ridesharing atau antar jemput.

\section{DASAR TEORI}

\section{Green Transportation}

Mulyani (2015), mendefinisikan green transportation sebagai upaya untuk memenuhi kebutuhan mobilitas transportasi generasi saat ini tanpa mengurangi kemampuan generasi mendatang dalam memenuhi kebutuhan mobilitasnya. Sistem green transportation atau bisa juga disebut sebagai sustainable transportation dapat dikatakan sebagai suatu sistem transportasi yang mampu mengakomodasi aksesibilitas semaksimal mungkin dengan dampak negatif yang seminimal mungkin. Bukan hanya menjadi sekedar alat transportasi yang dijalankan dalam waktu dekat, akan tetapi juga harus mempunyai dampak yang paling minimal di masa depan.

\section{Ridesharing, Carpooling, Vanpooling}

Online TDM Encyclopedia (2015) menerangkan bahwa kata ridesharing tersebut merujuk pada kata carpooling dan vanpooling, di mana sebuah kendaraan membawa penumpang tambahan ketika melakukan perjalanan dengan jarak tempuh tambahan seminimal mungkin. Hal ini tidak termasuk tambahan perjalanan di mana, si empunya kendaraan yang biasanya sekaligus sopir secara khusus mengantar penumpang tambahan tersebut menuju tujuan lain yang berbeda. Secara sederhana, ridesharing dapat didefinisikan sebagai proses menumpang dan pemberian tumpangan kepada traveller lain agar berkendara bersama-sama dalam satu kendaraan (Rachman dan Kusumantoro, 2013).

Carpooling secara umum biasanya menggunakan mobil milik pribadi sedangkan vanpooling umumnya berupa mobil rental yang bisa berupa fasilitas dari pemilik usaha, organisasi nirlaba, ataupun bantuan dari instansi pemerintah. Selain itu menurut Rachman dan Kusumantoro (2013), perbedaan mendasar antara carpooling dan vanpooling terletak 
pada jenis kendaraan yang digunakan dan jumlah pelaku perjalanan, yang mana carpooling terdiri dari $2-6$ penumpang, sedangkan vanpooling terdiri atas $7-15$ penumpang.

Menurut Jacobson dan King (2009) salah satu keunggulan dari carpooling yang mampu dilihat secara langsung adalah peningkatan efisiensi bahan bakar, karena dengan penerapan carpooling, mobil akan mengangkut lebih banyak orang dengan konsumsi bahan bakar yang relatif sama.

\section{Pemilihan Moda}

Secara sederhana moda berkaitan dengan jenis transportasi yang digunakan. Pilihan pertama biasanya berjalan kaki atau menggunakan kendaraan. Jika menggunakan kendaraan, pilihannya adalah kendaraan pribadi (sepeda, sepeda motor, mobil) atau angkutan umum (bus, becak dan lain-lain). Jika angkutan umum yang digunakan, jenisnya bermacam-macam - oplet, kereta api, becak, dan lain-lain. Orang yang hanya mempunyai satu pilihan moda saja disebut dengan captive terhadap moda tersebut. Jika terdapat lebih dari satu moda, moda yang dipilih biasanya yang mempunyai rute terpendek, tercepat, atau termurah, atau kombinasi dari ketiganya. Faktor lain yang mempengaruhi adalah ketidaknyamanan dan keselamatan. Hal seperti ini harus dipertimbangkan dalam pemilihan moda. (Tamin, 2000).

Bruton (1985), sebagaimana dikutip dari Tamin (2000) mendefinisikan pemilihan moda sebagai pembagian secara proporsional dari semua orang yang melakukan perjalanan terhadap sarana trasportasi yang ada, yang dapat dinyatakan dalam bentuk fraksi, rasio dan prosentase terhadap jumlah orang yang menggunakan masing-masing sarana transportasi seperti kendaraan pribadi, bus, pesawat terbang, kereta api dan angkutan umum lainnya. Beberapa prosedur pemilihan moda memodelkan pergerakan dengan hanya dua buah moda transportasi, yaitu antara angkutan umum dan angkutan pribadi.

\section{Transportation Demand Management}

Erik Ferguson (2007) mendefinsikan sebagai sebuah seni memodifikasi perilaku perjalanan, yang biasanya digunakan untuk menghindari pengeluaran biaya ekspansi transportasi yang lebih tinggi. TDM membutuhkan kerjasama dari berbagai pihak yang termasuk pengembang, pemilik lahan, asosiasi bisnis, dan pemerintah. TDM seperti yang dikutip oleh Rudy Setiawan (2007) dari Online TDM Encyclopedia (2006a) meliputi semua metode yang dapat meningkatkan pemanfaatan fasilitas dan sarana transportasi yang telah ada dengan lebih efisien dengan mengatur atau meminimalisasi pemanfaatan kendaraan bermotor dengan mempengaruhi perilaku perjalanan yang meliputi: frekuensi, tujuan, moda, dan waktu perjalanan.

Tujuan utama dari TDM, seperti yang dikutip Rudy Setiawan (2007) dari Harata (1994) dan Zupan (1994) adalah untuk mengurangi jumlah kendaraan yang menggunakan sistem jaringan jalan dengan menyediakan berbagai pilihan mobilitas (kemudahan melakukan perjalanan) bagi siapa saja yang berkeinginan untuk melakukan perjalanan. Sedangkan tujuan umum dari TDM adalah meningkatkan efisiensi pergerakan lalu lintas secara menyeluruh dengan menyediakan aksesbilitas yang tinggi dengan cara menyeimbangkan antara permintaan (demand) dan saranan penunjang (supply) yang tersedia, penghematan penggunaan bahan bakar dan waktu tempuh perjalanan secara lebih efisien. Menurut Rachman dan Kusumantoro (2013) ridesharing merupakan salah satu strategi TDM yang bertujuan untuk memaksimalkan pergerakan orang bukan kendaraan.

\section{METODE}

Metode yang digunakan pada penelitian ini antara lain sebagai berikut. Kuisioner dibuat menjadi 2 bagian, bagian pertama terdiri atas pertanyaan untuk mengetahui karakteristik responden, sedangkan bagian kedua terdiri atas pertanyaan untuk mengetahui potensi ridesharing dan antar jemput pegawai. Skenario formulasi dapat dilihat pada Gambar 1 sedangkan uraian skenario formulasi ridesharing dan antar jemput dapat dilihat pada Tabel 1. 


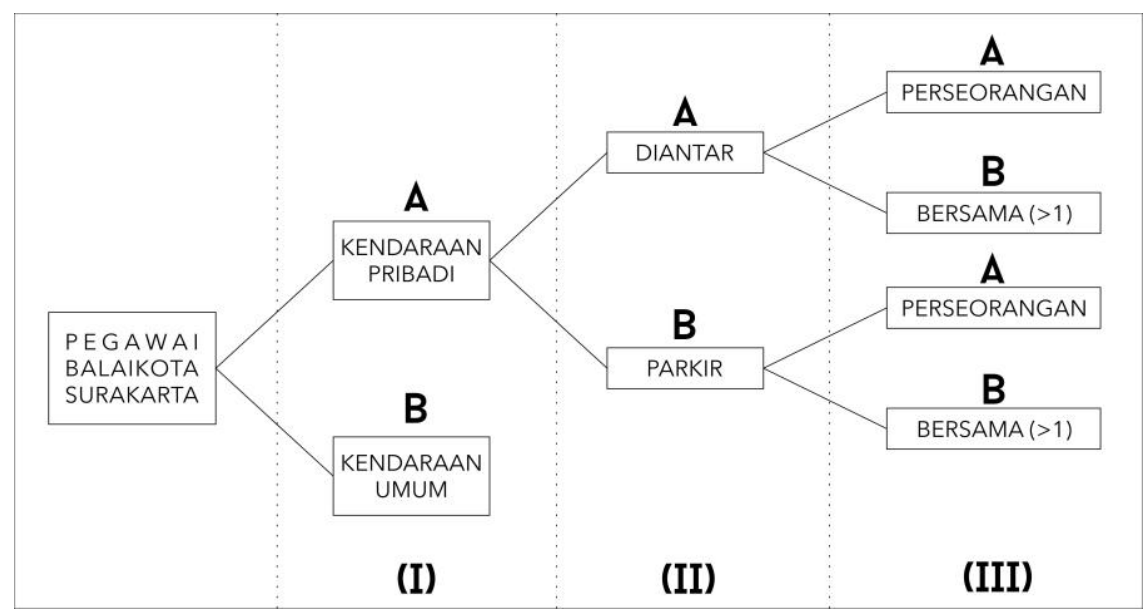

Gambar 1. Skenario Formulasi Potensi Ridesharing dan Antar Jemput

Tabel 1. Skenario Formulasi Ridesharing dan Antar Jemput Pegawai

\begin{tabular}{clll}
\hline \multirow{2}{*}{ No. } & \multicolumn{1}{c}{ Skenario } & \multicolumn{1}{c}{ Keputusan } & \multicolumn{1}{c}{ Potensi } \\
\hline \multirow{2}{*}{ 1. } & $1 \mathrm{~A}-2 \mathrm{~A}-3 \mathrm{~A}$ & Bersedia & Pengurangan penggunaan kendaraan pribadi \\
\cline { 3 - 4 } & \multirow{2}{*}{ 2. } & Tidak Bersedia & Tidak ada \\
\hline 3. & $1 \mathrm{~A}-2 \mathrm{~B}-3 \mathrm{~A}$ & Bersedia & Pengurangan penggunaan kendaraan pribadi \\
\cline { 3 - 4 } & & Tidak Bersedia & Tidak ada \\
\hline 4. & $1 \mathrm{~A}-2 \mathrm{~B}-3 \mathrm{~B}$ & Tidak Bersedia & Pengurangan penggunaan kendaraan pribadi dan fasilitas parkir \\
\cline { 2 - 4 } & & Tidak Bersedia & Tidak ada \\
\hline
\end{tabular}

Sebelum dilakukan survei utama terlebih dahulu dilakukan survei pendahuluan dengan menyebar 30 kuisioner secara acak. Hasil dari survei pendahuluan digunakan untuk menghitung jumlah responden yang diperlukan pada saat survei utama. Distribusi sampel dilakukan secara acak dengan perbandingan antara jumlah sepeda motor dan mobil adalah 4:1 yang diketahui berdasarkan data dari UP3AD Kota Surakarta.

Langkah selanjutnya adalah mengolah data kuisioner. Data kuisioner direkap dengan bantuan Microsoft Excel untuk kemudian dilakukan analisis dengan metode analisis deskriptif. Hasilnya berupa potensi penggunaan ridesharing dan antar jemput pegawai Balaikota Surakarta.

\section{HASIL DAN PEMBAHASAN}

Hasil dari penelitian adalah diketahui karakteristik dan potensi ridesharing serta antar jemput pegawai yang dapat dilihat pada Gambar 2 pada halaman 5. Karakteristik pegawai di Balaikota Surakarta pengguna motor terdiri atas $52,18 \%$ perempuan dan $47,82 \%$ laki laki. Sementara untuk pengguna mobil terdiri atas atas $53,20 \%$ perempuan dan $46,80 \%$ laki laki.

Karakteristik pegawai berdasarkan usia dapat dilihat pada Gambar 3 pada halaman 5. Berdasarkan data pada gambar, 44,10\% pegawai di Balaikota Surakarta yang menggunakan motor berusia 30-39 tahun dan 56,90\% pegawai adalah gabungan dari beberapa kategori usia lain. Sementara jumlah pegawai di Balaikota Surakarta yang menggunakan mobil terdiri atas 53,19\% pegawai berusia $40-49$ tahun dan $46,81 \%$ pegawai adalah gabungan dari beberapa kategori usia lain. 


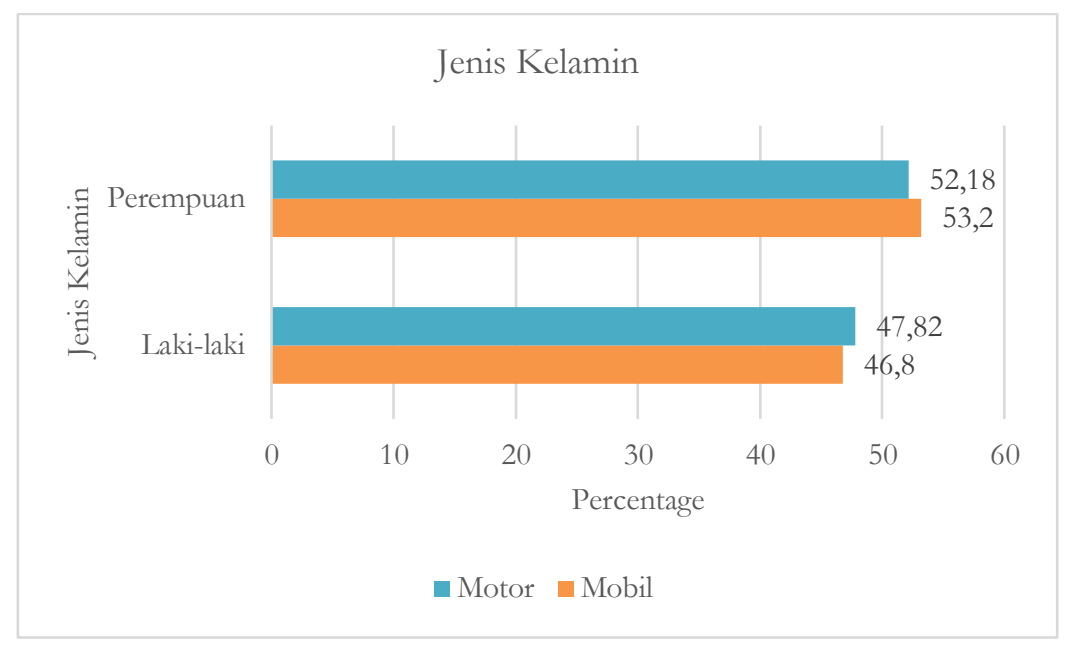

Gambar 2. Karakteristik Pegawai Balaikota Berdasarkan Jenis Kelamin.

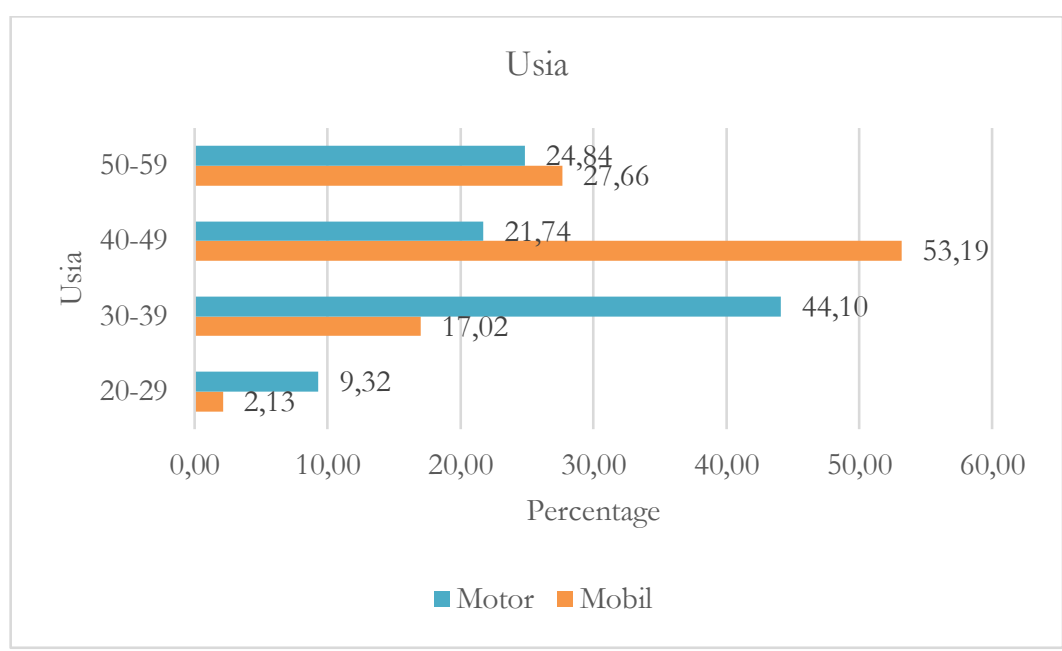

Gambar 3. Karakteristik Pegawai Balaikota Berdasarkan Usia.

Pada Gambar 4 dapat dilihat, jumlah pegawai di Balaikota Surakarta yang menggunakan motor terdiri atas 52,80\% pegawai yang berpendidikan S1 dan 47,20\% sisanya merupakan gabungan dari beberapa kategori pendidikan lainnya. Sementara untuk pengguna mobil terdiri atas 57,45\% pegawai yang berpendidikan S1 dan $42,55 \%$ sisanya merupakan pegawai yang berpendidikan S2.

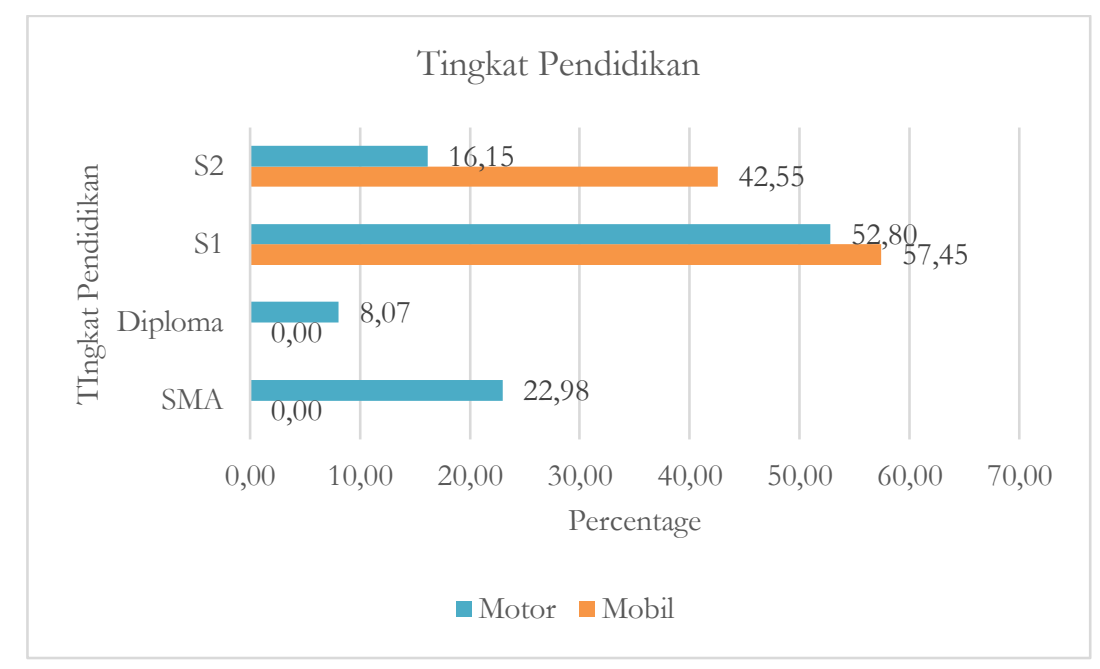

Gambar 4. Karakteristik Pegawai Balaikota Berdasarkan Tingkat Pendidikan. 


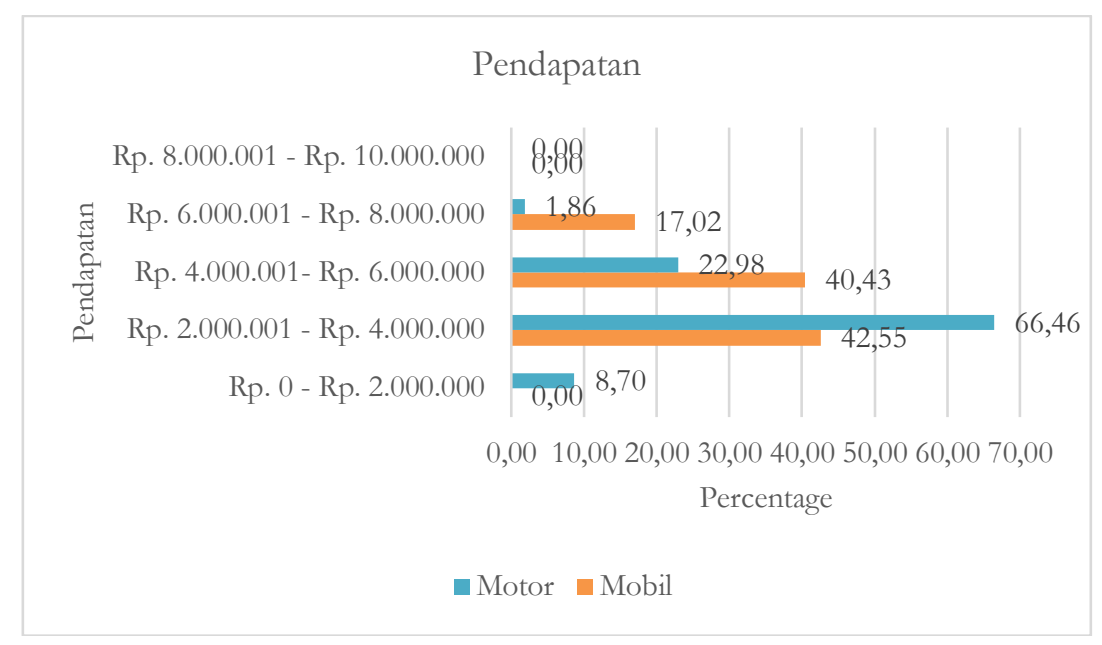

Gambar 5. Karakteristik Pegawai Balaikota Berdasarkan Pendapatan.

Dapat dilihat pada Gambar 5 bahwa jumlah pegawai pengguna motor terdiri atas $66,46 \%$ pegawai berpendapatan Rp. 2.000.001,00 - Rp. 4.000.000,00 sedangkan 33,54\% lainnya merupakan gabungan dari pegawai yang memiliki pendapatan yang ada pada 4 kategori lainnya. Sementara pegawai pengguna mobil sebagian besar terdiri atas 42,55\% pegawai berpendapatan Rp. 2.000.001,00 - Rp. 4.000.000,00, dan 57,45\% sisanya merupakan gabungan dari 4 kategori pendapatan yang lainnya.

Pada Gambar 6, jumlah pegawai di Balaikota Surakarta yang menggunakan motor terdiri atas 21,12\% pegawai yang memiliki pangkat/golongan IIIA dan 78,88\% sisanya merupakan gabungan dari beberapa pangkat/golongan lainnya. Sementara untuk pengguna mobil, baik pegawai yang memiliki pangkat/golongan IIIC maupun IVA sama - sama memiliki prosentase sebesar $29,79 \%$ dan $40,42 \%$ sisanya merupakan gabungan dari pegawai yang memiliki jenis pangkat/golongan yang berbeda.

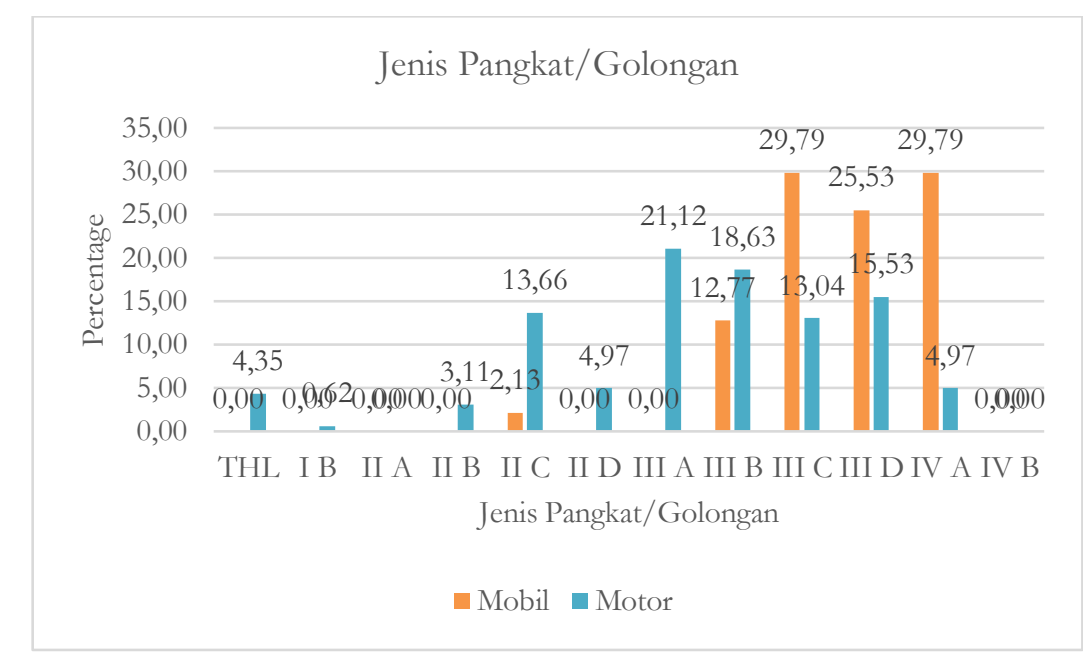

Gambar 6. Karakteristik Pegawai Balaikota Berdasarkan Pangkat/Golongan. 
Tabel 2. Kesediaan Responden Melakukan Ridesharing

\begin{tabular}{|c|c|c|c|c|c|c|c|}
\hline \multirow[b]{2}{*}{ Jenis Kendaraan } & \multirow[b]{2}{*}{ Skenario } & \multicolumn{3}{|c|}{ Jumlah } & \multicolumn{3}{|c|}{ Prosentase } \\
\hline & & Bersedia & $\begin{array}{c}\text { Tidak } \\
\text { Bersedia }\end{array}$ & Total & Bersedia & $\begin{array}{c}\text { Tidak } \\
\text { Bersedia }\end{array}$ & Total \\
\hline \multirow{4}{*}{ Mobil (1) } & $1 \mathrm{~A}-2 \mathrm{~A}-3 \mathrm{~A}$ & 2 & 5 & 7 & $4,26 \%$ & $10,64 \%$ & $14,89 \%$ \\
\hline & $1 \mathrm{~A}-2 \mathrm{~A}-3 \mathrm{~B}$ & 0 & 0 & 0 & $0,00 \%$ & $0,00 \%$ & $0,00 \%$ \\
\hline & $1 \mathrm{~A}-2 \mathrm{~B}-3 \mathrm{~A}$ & 21 & 16 & 37 & $44,68 \%$ & $34,04 \%$ & $78,72 \%$ \\
\hline & $1 \mathrm{~A}-2 \mathrm{~B}-3 \mathrm{~B}$ & 3 & 0 & 3 & $6,38 \%$ & $0,00 \%$ & $6,38 \%$ \\
\hline \multicolumn{2}{|c|}{ Jumlah (1) } & 26 & 21 & 47 & $55,32 \%$ & $44,68 \%$ & $100,00 \%$ \\
\hline \multirow{4}{*}{ Motor (2) } & $1 \mathrm{~A}-2 \mathrm{~A}-3 \mathrm{~A}$ & 5 & 8 & 13 & $3,11 \%$ & $4,97 \%$ & $8,07 \%$ \\
\hline & $1 \mathrm{~A}-2 \mathrm{~A}-3 \mathrm{~B}$ & 0 & 0 & 0 & $0,00 \%$ & $0,00 \%$ & $0,00 \%$ \\
\hline & $1 \mathrm{~A}-2 \mathrm{~B}-3 \mathrm{~A}$ & 45 & 100 & 145 & $27,95 \%$ & $62,11 \%$ & $90,06 \%$ \\
\hline & $1 \mathrm{~A}-2 \mathrm{~B}-3 \mathrm{~B}$ & 1 & 2 & 3 & $0,62 \%$ & $1,24 \%$ & $1,86 \%$ \\
\hline \multicolumn{2}{|c|}{ Jumlah (2) } & 51 & 110 & 161 & $31,68 \%$ & $68,32 \%$ & $100,00 \%$ \\
\hline
\end{tabular}

Tabel 2 menunjukkan jumlah pegawai yang bersedia menggunakan ridesharing adalah sebesar 55,32\% pegawai pengguna mobil dan 31,68\% pegawai pengguna sepeda motor. Mayoritas pegawai di Balaikota Surakarta menggunakan fasilitas parkir mobil untuk kerja setiap hari, dapat dilihat dari seluruh pegawai terdapat 85,10\% pengguna mobil yang termasuk dalam skenario $1 \mathrm{~A}-2 \mathrm{~B}-3 \mathrm{~A}$ (pengguna kendaraan pribadi - menggunakan fasilitas parkir - berkendara sendiri) sebesar 78,72\% dan skenario 1A-2B-3B (pengguna kendaraan pribadi - menggunakan fasilitas parkir - berkendara bersama) sebesar 6,38\%. Dari jumlah tersebut hanya sebesar 51,06\% saja pegawai pengguna mobil yang bersedia menggunakan ridesharing, sedangkan 34,04\% sisanya tidak bersedia menggunakan ridesharing. Dengan mengasumsikan 1 pengguna berbagi dengan 1 pengguna mobil yang lain, maka dapat diharapkan potensi pengurangan penggunaan fasilitas parkir mobil di kompleks Balaikota Surakarta sebesar 25,53\% yang didapat dari jumlah pegawai pengguna mobil dan fasilitas parkir di Balaikota Surakarta yang bersedia menggunakan ridesharing dibagi dua. Begitu pula dengan pengguna sepeda motor dimana terdapat sebesar $91,92 \%$ pegawai yang menggunakan sepeda motor dan fasilitas parkir di Balaikota. Jumlah tersebut terdiri atas skenario 1A-2B-3A (pengguna kendaraan pribadi - menggunakan fasilitas parkir - berkendara sendiri) sebesar 90,06\% dan skenario 1A-2B-3B (pengguna kendaraan pribadi - menggunakan fasilitas parkir - berkendara bersama) sebesar $1,86 \%$. Dari jumlah tersebut hanya ada sebesar $28,57 \%$ pegawai pengguna motor yang bersedia menggunakan ridesharing, sedangkan sisanya 63,35\% tidak bersedia menggunakannya. Dengan asumsi yang sama maka diharapkan terdapat potensi pengurangan penggunaan fasilitas parkir motor di Balaikota Surakarta sebesar 14,29\% yang didapat dari jumlah pegawai pengguna sepeda motor dan fasilitas parkir di Balaikota Surakarta dibagi dua.

Penggunaan ridesharing secara tidak langsung berdampak pada berkurangnya penggunaan mobil dan sepeda motor oleh pegawai Balaikota Surakarta, sehingga dari data jumlah pegawai yang bersedia dan ditambah asumsi 1 pengguna berbagi dengan 1 pengguna mobil atau sepeda motor yang lain dapat diharapkan terjadi potensi pengurangan penggunaan mobil oleh pegawai Balaikota Surakarta sebesar 27,66\% yang didapat dari prosentase pegawai pengguna mobil yang bersedia menggunakan ridesharing sebesar 55,32\% dibagi dua, serta penurunan penggunaan sepeda motor oleh pegawai Balaikota Surakarta sebesar 15,84\% yang didapat dari jumlah pegawai pengguna motor yang bersedia menerapkan ridesharing sebesar 31,68\% dibagi dua. 
Tabel 3. Kesediaan Responden Melakukan Antar Jemput

\begin{tabular}{|c|c|c|c|c|c|c|c|}
\hline \multirow[b]{2}{*}{ Jenis Kendaraan } & \multirow[b]{2}{*}{ Skenario } & \multicolumn{3}{|c|}{ Jumlah } & \multicolumn{3}{|c|}{ Prosentase } \\
\hline & & Bersedia & $\begin{array}{c}\text { Tidak } \\
\text { Bersedia }\end{array}$ & Total & Bersedia & $\begin{array}{c}\text { Tidak } \\
\text { Bersedia }\end{array}$ & Total \\
\hline \multirow{4}{*}{ Mobil (1) } & $1 \mathrm{~A}-2 \mathrm{~A}-3 \mathrm{~A}$ & 5 & 2 & 7 & $10,64 \%$ & $4,26 \%$ & $14,89 \%$ \\
\hline & $1 \mathrm{~A}-2 \mathrm{~A}-3 \mathrm{~B}$ & 0 & 0 & 0 & $0,00 \%$ & $0,00 \%$ & $0,00 \%$ \\
\hline & $1 \mathrm{~A}-2 \mathrm{~B}-3 \mathrm{~A}$ & 14 & 23 & 37 & $29,79 \%$ & $48,94 \%$ & $78,72 \%$ \\
\hline & $1 \mathrm{~A}-2 \mathrm{~B}-3 \mathrm{~B}$ & 3 & 0 & 3 & $6,38 \%$ & $0,00 \%$ & $6,38 \%$ \\
\hline \multicolumn{2}{|c|}{ Jumlah (1) } & 22 & 25 & 47 & $46,81 \%$ & $53,19 \%$ & $100,00 \%$ \\
\hline \multirow{4}{*}{ Motor (2) } & $1 \mathrm{~A}-2 \mathrm{~A}-3 \mathrm{~A}$ & 6 & 7 & 13 & $3,73 \%$ & $4,35 \%$ & $8,07 \%$ \\
\hline & $1 \mathrm{~A}-2 \mathrm{~A}-3 \mathrm{~B}$ & 0 & 0 & 0 & $0,00 \%$ & $0,00 \%$ & $0,00 \%$ \\
\hline & $1 \mathrm{~A}-2 \mathrm{~B}-3 \mathrm{~A}$ & 57 & 88 & 145 & $35,40 \%$ & $54,66 \%$ & $90,06 \%$ \\
\hline & $1 \mathrm{~A}-2 \mathrm{~B}-3 \mathrm{~B}$ & 1 & 2 & 3 & $0,62 \%$ & $1,24 \%$ & $1,86 \%$ \\
\hline \multicolumn{2}{|c|}{ Jumlah (2) } & 64 & 97 & 161 & $39,75 \%$ & $60,25 \%$ & $100,00 \%$ \\
\hline
\end{tabular}

Mayoritas pegawai pengguna mobil menggunakan fasilitas parkir di Balaikota Surakarta yakni sebesar 85,10\% yang terdiri atas skenario 1A-2B-3A (pengguna kendaraan pribadi - menggunakan fasilitas parkir - berkendara sendiri) dengan prosentase sebesar $78,72 \%$ dan skenario $1 \mathrm{~A}-2 \mathrm{~B}-3 \mathrm{~B}$ (pengguna kendaraan pribadi - menggunakan fasilitas parkir - berkendara bersama) sebesar 6,38\%. Namun dari jumlah tersebut itu hanya 36,17\% pegawai pengguna mobil saja yang bersedia menggunakan fasilitas antar jemput pegawai, sedangkan sisanya sebanyak 48,94\% tidak bersedia menggunakannya. Penggunaan fasilitas antar jemput secara tidak langsung akan berdampak pada pengurangan penggunaan fasilitas parkir di Balaikota, sehingga dengan adanya 36,17\% pegawai pengguna mobil yang bersedia menggunakan fasilitas antar jemput pegawai ditambah asumsi pengguna yang bersedia yang tergolong dalam skenario 1A-2B-3B (pengguna kendaraan pribadi - menggunakan fasilitas parkir - berkendara bersama) merupakan pengendara mobil maka diharapkan terdapat potensi pengurangan penggunaan fasilitas parkir di Balaikota sebesar 36,17\%. Begitu pula pada pegawai pengguna sepeda motor, dimana mayoritas menggunakan fasilitas parkir motor di Balaikota Surakarta dengan prosentase sebesar 91,92\% yang terbagi ke dalam skenario $1 \mathrm{~A}$ 2B-3A (pengguna kendaraan pribadi - menggunakan fasilitas parkir - berkendara sendiri) dengan prosentase sebesar 90,06\% dan skenario 1A-2B-3B (pengguna kendaraan pribadi - menggunakan fasilitas parkir - berkendara bersama) sebesar $1,86 \%$. Tetapi jumlah pegawai yang bersedia menggunakan fasilitas antar jemput pegawai hanyalah 36,02\%, sedang sisanya sebesar 55,90\% tidak bersedia. Penggunaan fasilitas antar jemput akan berdampak langsung terhadap pengurangan penggunaan fasilitas parkir di Balaikota Surakarta, sehingga dari data tersebut ditambah asumsi pengguna yang bersedia yang tergolong dalam skenario 1A-2B-3B (pengguna kendaraan pribadi - menggunakan fasilitas parkir - berkendara bersama) merupakan pengendara motor maka akan terjadi reduksi penggunaan fasilitas parkir sepeda motor di Balaikota Surakarta sebesar 36,02\%.

Penggunaan fasilitas antar jemput juga secara langsung berdampak pada pengurangan jumlah kendaraan yang digunakan oleh pegawai Balaikota Surakarta, sehingga dari data yang ada dimana terdapat 46,81\% pegawai pengguna mobil yang bersedia ditambah asumsi pengguna yang bersedia yang tergolong dalam skenario $1 \mathrm{~A}-2 \mathrm{~B}-3 \mathrm{~B}$ (pengguna kendaraan pribadi - menggunakan fasilitas parkir - berkendara bersama) merupakan pengendara mobil maka diharapkan terdapat potensi pengurangan penggunaan mobil oleh pegawai Balaikota Surakarta sebesar $46,81 \%$. Begitu pula dengan pengguna sepeda motor di mana dengan adanya pegawai pengguna sepeda motor yang bersedia berpindah menggunakan fasilitas antar jemput sebesar 39,75\% ditambah asumsi yang sama maka akan terjadi pengurangan penggunaan sepeda motor oleh pegawai Balaikota Surakarta sebesar 39,75\%.

\section{SIMPULAN}


Berdasarkan hasil dari penelitian ini dapat disimpulkan bahwa karakteristik pegawai Balaikota Surakarta yang menggunakan sepeda motor terdiri atas 52,18\% perempuan. Mayoritas pegawai pengguna sepeda motor, yaitu sebesar 44,10\% merupakan kelompok umur 30 - 39 tahun, dan memiliki tingkat pendidikan S1 dengan prosentase $52,80 \%$. Selain itu mayoritas pegawai Balaikota Surakarta pengguna sepeda motor yaitu 66,46\% berpendapatan Rp. 2.000.001,00 - Rp. 4.000.000,00 dan sebanyak 21,12\% pegawai Balaikota Surakarta pengguna sepeda motor adalah pegawai dengan pangkat/golongan IIIA. Sedangkan pegawai Balaikota Surakarta pengguna mobil sebanyak $53,20 \%$ merupakan perempuan dan 53,19\% dari pegawai Balaikota Surakarta pengguna mobil merupakan kelompok umur 40 - 49 tahun. Selain itu pegawai Balaikota Surakarta pengguna mobil terdiri atas 57,45\% dengan pendidikan S1, dan 42,55\% pegawai Balaikota pengguna mobil berpendapatan Rp. 2.000.001,00 - Rp. 4.000.000,00. Untuk pangkat/golongan pegawai Balaikota Surakarta pengguna mobil dengan pangkat/golongan IIIC maupun IVA sama - sama memiliki prosentase sebesar $29,79 \%$.

Dari hasil penelitian ini pula dapat disimpulkan bahwa pegawai pengguna mobil yang bersedia menerapkan kebijakan ridesharing di Balaikota Surakarta adalah sebesar 55,32\%, sedangkan pegawai pengguna motor sebesar $31,68 \%$. Selain itu jumlah pegawai yang bersedia menggunakan fasilitas antar jemput di Balaikota Surakarta adalah sebesar $46,81 \%$ untuk pengguna mobil dan $39,75 \%$ untuk pengguna motor.

\section{UCAPAN TERIMAKASIH}

Terima kasih saya ucapkan kepada Dr Dewi Handayani, S.T, M.T. dan Amirotul MHM, S.T, M.Sc., yang telah membimbing dan memberi masukan kepada Peneliti dalam melakukan penelitian ini.

\section{REFERENSI}

Abrahamse, Wokje, dan Michael Keall. "Effectiveness of a web-based intervention to encourage carpooling to work: A case study of Wellington, New Zealand." Transport policy 21 (2012): 45-51.

Amey, Andrew, John Attanucci, and Rabi Mishalani. "Real-time ridesharing: opportunities and challenges in using mobile phone technology to improve rideshare services." Transportation Research Record: Journal of the Transportation Research Board 2217 (2011): 103-110.

Andriani, Dian Maria, and Nany Yuliastuti. "Penilaian Sistem Transportasi yang Mengarah Pada Green Transportasi di Kota Surakarta." Jurnal Pembangunan Wilayah \& Kota 9.2 (2013): 183-193.

Bruton, M.J.1985. Introduction To Transportation Planning. London: Hutchinson \& Co Ltd.

Ferguson, Erik. "Transportation demand management planning, development, and implementation." Journal of the American Planning Association 56.4 (1990): 442-456.

Gusnita, Dessy. "Green Transport: Transportasi Ramah Lingkungan Dan Kontribusinya Dalam Mengurangi Polusi Udara." Berita Dirgantara 11.2 (2010).

Jacobson, Sheldon H., and Douglas M. King. "Fuel saving and ridesharing in the US: Motivations, limitations, and opportunities." Transportation Research Part D: Transport and Environment 14.1 (2009): 14-21.

Krejcie, Robert V., and Daryle W. Morgan. "Determining sample size for research activities." Educational and psychological measurement 30.3 (1970): 607-610.

Miftakhurrohmah, Istianna. "Daya Dukung Ruang Terbuka Hijau dalam Mencapai Atribut Ruang Terbuka Hijau (Green Open Space) pada Konsep Kota Hijau Studi Kasus: Kota Surakarta." (2016).

Mulyani, IM Tri Hesti, dan B. Pat Ristara Gandhi. "Peranan Green Transportation untuk Mewujudkan Green Urban Area pada Kawasan Pusat Kota Simpanglima Semarang." 2015.

Oktariani, Ni Pt Emmy, P. Alit Suthanaya, and I. G. Putu Suparsa. "Analisis Kebutuhan Pengembangan Angkutan Khusus Karyawan pada Pusat Pemerintahan Kota Denpasar di Lumintang." Jurnal Spektran 3.1. 2015.

Online Transportation Encyclopedia, 2006c, Ridesharing: Car and V an Pooling,

http://www.vtpi.org/tdm/tdm34.htm

Diakses pada tanggal 4 Mei 2017

Parikesit, Danang.1993.Kemungkinan Penggunaan Teknik Stated Preference dalam Perencanaan Angkutan Umum.Forum Teknik Sipil No II/I - Agustus 1993. UGM Yogyakarta.

Rachman, Aditia Mulia, dan Iwan Pratoyo Kusumantoro. "Potensi Pengembangan Program Ridesharing Berdasarkan Preferensi Pekerja di Kawasan Perumahan Kemang Pratama Kota Bekasi." 2013.

Sarwono, Jonathan. "Metode Penelitian." Kuantitatif Kualitatif (2006).

Setiawan, Nugraha. "Penentuan Ukuran Sampel Memakai Rumus Slovin dan Tabel Krejcie-Morgan: Telaah Konsep dan Aplikasinya." Abstrak. 2007. 
Setiawan, R. "Potensi Penerapan Fasilitas Antar-Jemput Untuk Mengurangi Penggunaan Mobil Pribadi." Proceeding Seminar Sehari Purnabakti Prof. Dr. BS. Kusbianto, II-45 s/d II-54, ITB, Bandung. 2007.

Sistem Informasi Badan Pusat Statistik Kota Surakarta, Banyaknya Pegawai

Negeri Sipil (PNS) di Lingkungan Pemerintah Kota Surakarta Menurut Unit Kerja,Pendidikan dan Jenis Kelamin di Surakarta th. 2014. https://surakartakota.bps.go.id/linkTabelStatis/view/id/9.

Diakses pada tanggal 29 April 2017

Sistem Informasi UP3AD Kota Surakarta, Rincian Luas Wilayah, Jumlah, dan

Kepadatan Penduduk serta Jumlah Kendaraan Bermotor menurut Kecamatan di Wilayah UP3AD Kota Surakarta.

https://bppd.jatengprov.go.id/up3ad-kota-surakarta/

Diakses pada tanggal 26 Agustus 2017

Sugiyono. 2011. Metode Penelitian Kuantitatif Kualitatif dan R\&D. Bandung: Alfabeta

Tamin, O.Z.2000. Perencanaan dan Pemodelan Transportasi Jilid 1.ITB Bandung.

Walpole, R. E., 1995, Pengantar Statistika, Gramedia Pustaka Utama, Jakarta 